\title{
Adverse birth outcome: a comparative analysis between cesarean section and vaginal delivery at Felegehiwot Referral Hospital, Northwest Ethiopia: a retrospective record review [Corrigendum]
}

\author{
Abebe Eyowas F, Negasi AK, Aynalem GE, Worku AG. \\ Pediatric Health, Medicine and Therapeutics 2016;7:65-70 \\ On page 65 Abel Fekadu Dadi should have been listed as an \\ author. The incorrect author list was:
}

Fantu Abebe Eyowas ${ }^{1}$

Ashebir Kidane Negasi ${ }^{1}$

Gizachew Eyassu Aynalem ${ }^{1}$

Abebaw Gebeyehu Worku

The correct author list should have been:

Fantu Abebe Eyowas ${ }^{1}$

Ashebir Kidane Negasi ${ }^{1}$

Gizachew Eyassu Aynalem ${ }^{1}$

Abebaw Gebeyehu Worku

Abel Fekadu Dadi ${ }^{2}$

\section{Publish your work in this journal}

Pediatric Health, Medicine and Therapeutics is an international, peerreviewed, open access journal publishing original research, reports, editorials, reviews and commentaries. All aspects of health maintenance, preventative measures and disease treatment interventions are addressed within the journal. Practitioners from all disciplines are invited to submit their work as well as healthcare researchers and patient support groups. The manuscript management system is completely online and includes a very quick and fair peer-review system. Visit http://www.dovepress.com/ testimonials.php to read real quotes from published authors. 